\title{
Simulink Based Analysis and Realization of Solar PV System
}

\author{
S. Badie Asghar, R. K. Singh \\ ${ }^{1}$ Department of Electrical and Electronics Engineering, MACET, Bihar, India \\ ${ }^{2}$ Department of Electrical Engineering, MIT, Bihar, India \\ Email: s.b.asghar2010@gmail.com, rafiq.abuturab@gmail.com
}

Received 28 June 2015; accepted 27 October 2015; published 30 October 2015

Copyright (C) 2015 by authors and Scientific Research Publishing Inc.

This work is licensed under the Creative Commons Attribution International License (CC BY).

http://creativecommons.org/licenses/by/4.0/

(c) (i) Open Access

\begin{abstract}
Non-conventional energy resources are increasingly used to fulfill load demands. Before using such energy sources, the very important thing is analysis at the basic level. This paper presents analysis and realization of solar PV system. The current-voltage and power-voltage characteristics of solar PV array changes as parameters like solar insolation, and temperature changes. These characteristics are found and realized by using MATLAB software.
\end{abstract}

\section{Keywords}

Effect of Ambient Conditions, Modeling of PV Cell, Series Parallel Connection of PV Cells, Solar PV System

\section{Introduction}

One of the major concerns in the power sector is the day-to-day increasing power demand but the unavailability of enough resources to meet the power demand using the conventional energy sources. Demand has increased for renewable sources of energy to be utilized along with conventional systems to meet the energy demand. Renewable sources like wind energy and solar energy are the major energy sources which are being utilized in this regard. The continuous use of fossil fuels has caused the fossil fuel deposit to be reduced and has affected the environment emptying the biosphere and gradually adding to global warming.

Solar energy is widely available that has made it possible to yield it and utilize it properly. Solar energy can be a standalone generating unit or can be a grid connected generating unit depending on the availability of grid closeness. Thus it can be used to power rural areas where the availability of grids is very low. Another advantage of using solar energy is the portable operation whenever necessary. 


\section{Solar PV System}

Photovoltaic cells convert radiant energy from the sun directly into electricity. Photovoltaic cell provides a clean, reliable energy without consuming fossil, and is free from hazardous product. Sun is the mother of all energies (except nuclear and geothermal) that provides almost all the energy needed to support life, and can be used in variety of applications. On average, the earth receives about $1.2 \times 10^{17} \mathrm{~W}$ of solar power. The challenge for a sustainable future is to tap a tiny fraction of this energy to supply the relatively modest demands of human activities. The increasing use of these solar cells is linked to economic, efficiency and reliability factors and recent advances in solid state technologies has given a boost to the attractiveness of solar cells with high efficiency solar cells now available. A Schematic block diagram of a PV cell is shown in Figure 1.

1) I-V Characteristics of solar cell

Solar cell generator is neither a constant voltage nor a constant current source. The current is proportional to solar insolation and voltage is a function of the current required by the load [1].

A typical I-V characteristic of the solar cell for a certain ambient irradiation $S$ and a certain fixed cell temperature $\mathrm{T}$ is shown in Figure 2. For a resistive load, the load characteristic is a straight line with slope $\mathrm{I} / \mathrm{V}=1 / \mathrm{R}$. It should be pointed out that the power delivered to the load depends on the value of the resistance only.

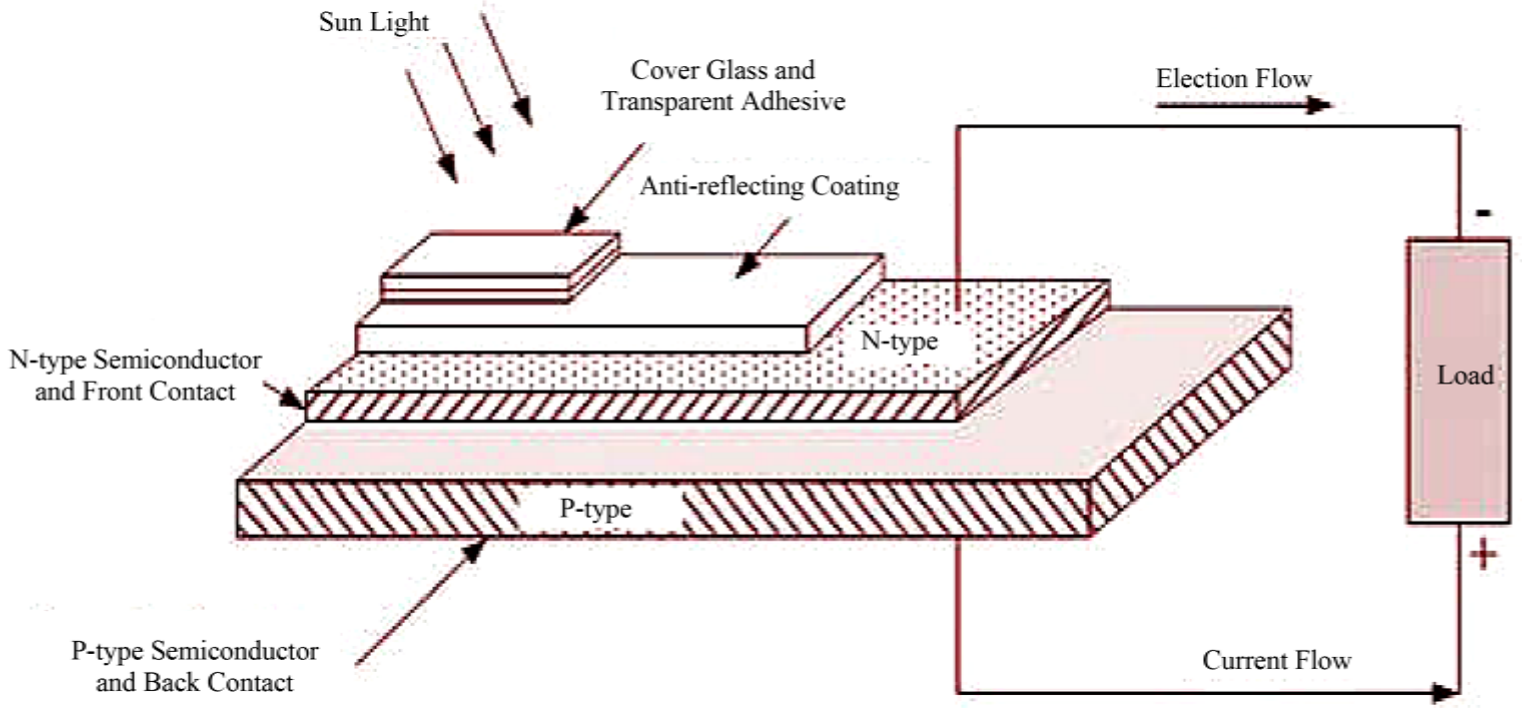

Figure 1. Schematic diagram of PV cell.

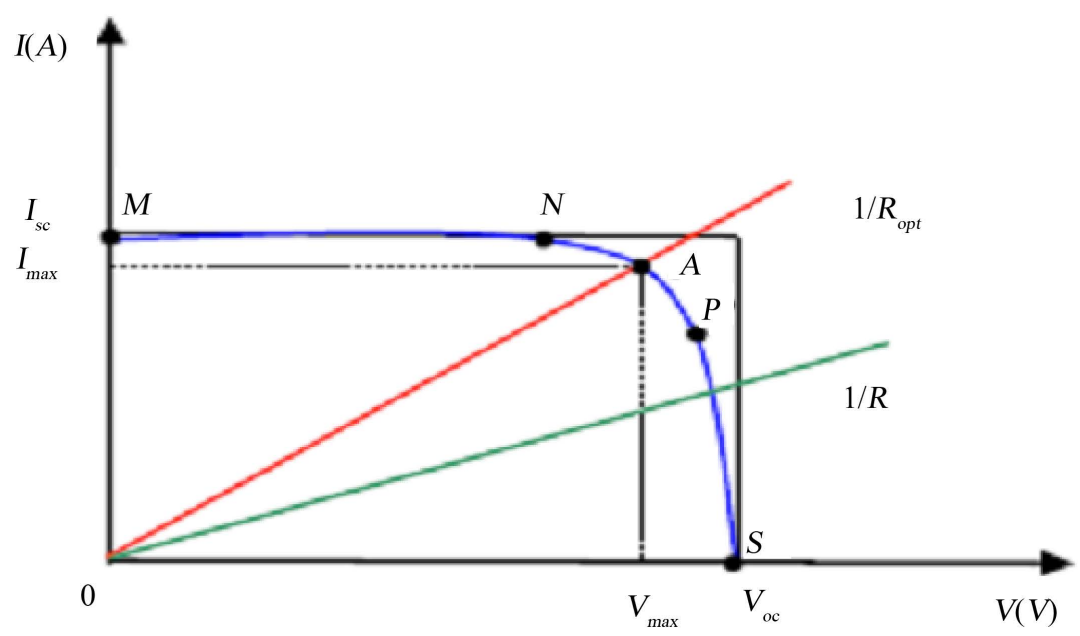

Figure 2. I-V characteristics of solar cell. 
2) Effect of Ambient Conditions on I-V Characteristics of PV Cell

The I-V characteristics of a PV cell is weather dependent, the effect of change in ambient temperature and solar insolation on the I-V characteristics is shown in Figure 3 and Figure 4 that the open circuit voltage decreases linearly with the increase in the cell temperature and open circuit voltage increases logarithmically with the ambient irradiation, while the short circuit current is a linear function of the ambient irradiation.

3) Effect of Series and Parallel Connection on I-V Characteristics of PV Cell

4) PV Generator Hierarchy

\section{Modeling of Photovoltaic Cell}

Photovoltaic (PV) system directly converts sunlight into electricity. The basic device of a PV system is the PV cell. Cells may be grouped to form panels or arrays. The voltage \&current available at the terminals of a PV device may directly feed small loads such as lighting systems and DC motors. More sophisticated applications require electronic converters to process the electricity from the PV device.These converters may be used to regulate the voltage and current at the load, to control the power flow in grid-connected systems, and mainly to track the maximum power point (MPP) of the device [2].

A PV device may be any element that converts sunlight into electricity. The elementary PV device is the PV cell. A set of connected cells form a panel. Panels are generally composed of series cells in order to obtain large output voltages. Panels with large output currents are achieved by increasing the surface area of the cells or by connecting cells in parallel. A PV array may be either a panel or a set of panels connected in series or parallel to form large PV systems. This paper focuses on PV arrays and shows how to obtain the parameters of the I-V equation from practical data obtained in datasheets [3]. Series \& parallel connection \& PV hierarchy is shown in Figure 5 \& Figure 6 respectively.

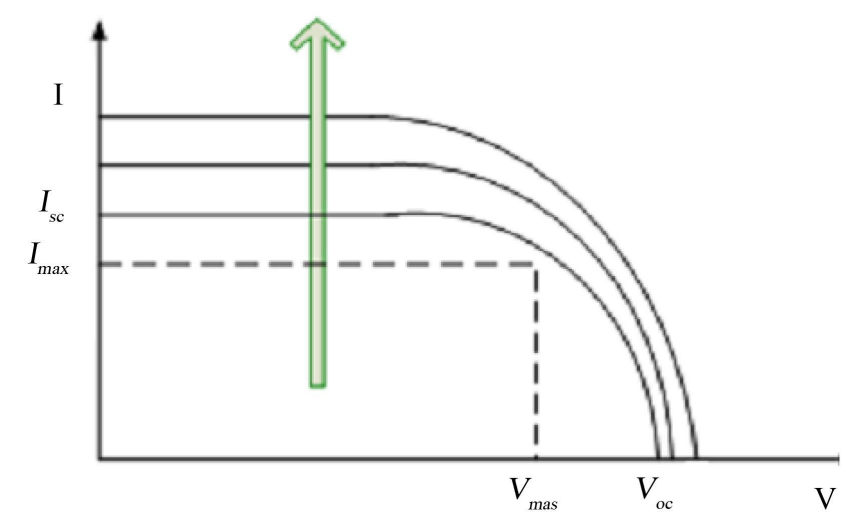

Figure 3. Effect of temperature on I-V characteristics.

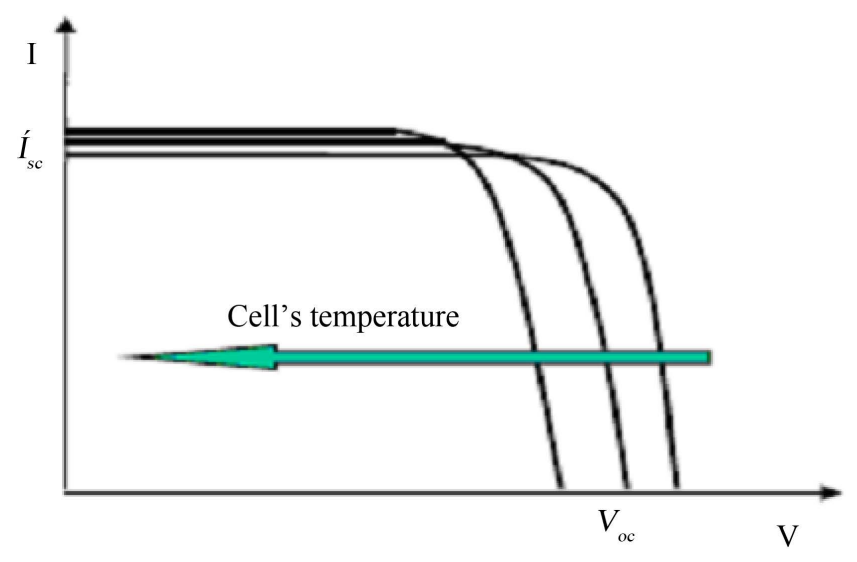

Figure 4. Effect of Solar irradiation on I-V characteristics. 


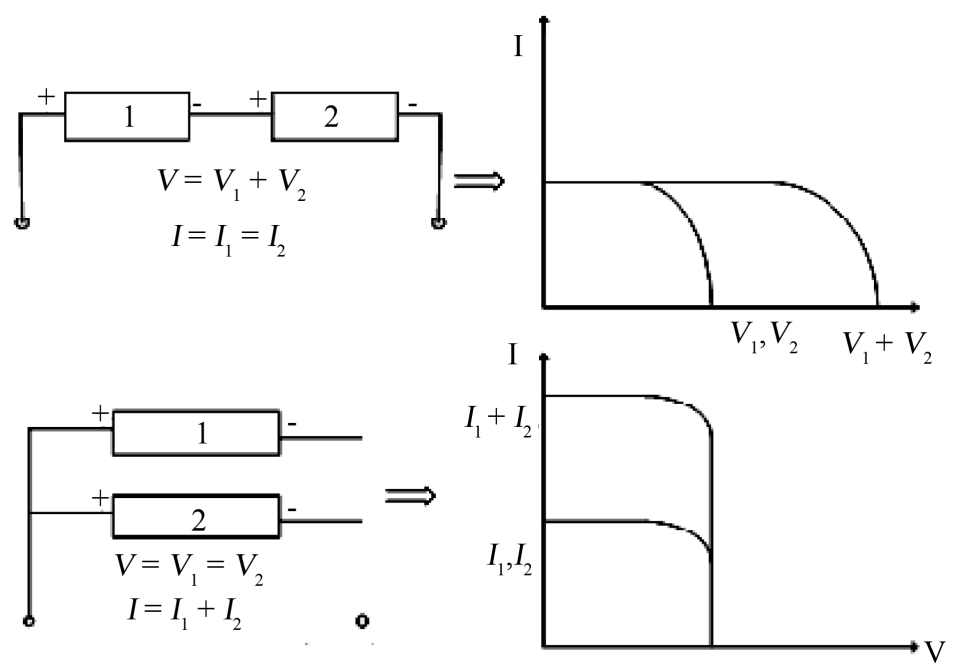

Figure 5. Series \& Parallel connection on I-V characteristics.

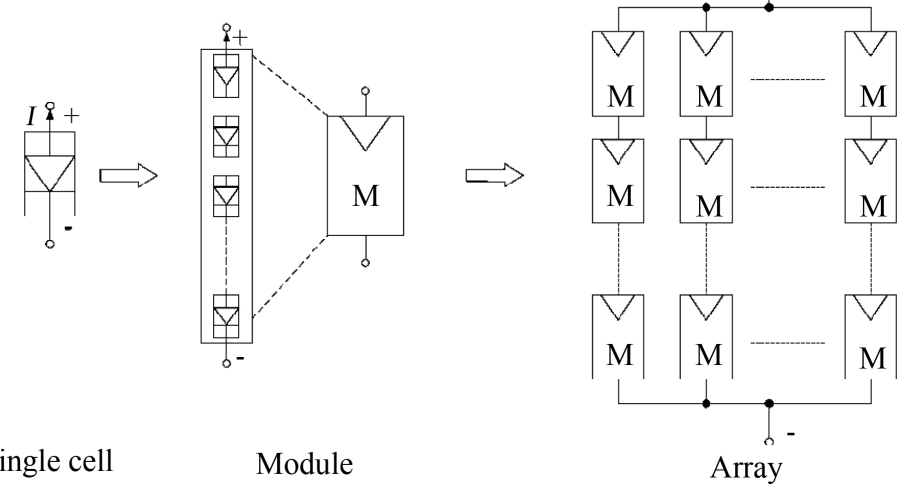

Figure 6. PV generator hierarchy.

\subsection{Simplest Model (Ideal Case)}

The simplest model of a PV cell and its equivalent circuit is presented in Figure that consists of an ideal current source in parallel with an ideal diode with zero series resistance, infinite shunt resistance and unity ideality factor for junction.

The output current $\left(I_{C}\right)$ from the PV cell is found by applying the Kirchoff's current law on the equivalent circuit in Figure 7.

$$
I_{C}=I_{S C}-I_{d}
$$

where $I_{s c}$ is a short circuit current. The diode current $I_{d}$ is given by Shockley diode equation.

$$
I_{d}=I_{0}\left(\mathrm{e}^{\frac{q V_{d}}{k T_{c}}}\right)
$$

$V_{d}$ is the voltage across the diode $(D)$. For the ideal case, this voltage is equal to the cell voltage, $V_{c}$;

$k$ is Boltzmann constant $\left(1.38 \times 10^{-23} \mathrm{~J} / \mathrm{K}\right)$;

$q$ is electron charge $\left(1.602 \times 10^{-19} \mathrm{C}\right)$;

$I_{0}$ is reverse saturation current of diode $(0.000025 \mathrm{~A})$;

$T_{c}$ is reference cell operating temperature $\left(25^{\circ} \mathrm{C}\right)$.

Using above equations, the current and voltage of the PV cell can be written as: 


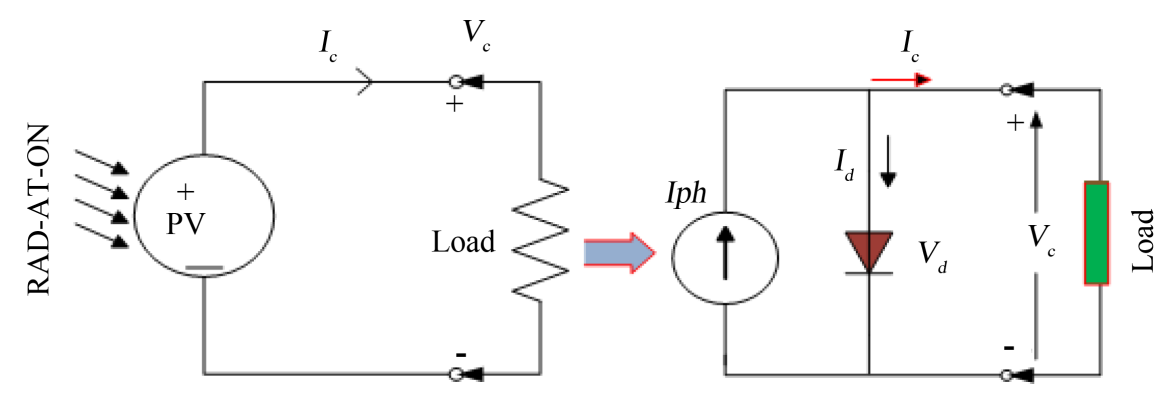

Figure 7. Equivalent Circuit of PV cell (Ideal case).

$$
\begin{gathered}
I_{c}=I_{P h}-I_{0}\left(\mathrm{e}^{\frac{q V_{c}}{k T_{c}}-1}\right) \\
V_{c}=\frac{k T_{c}}{q} \ln \left(\frac{I_{P h}+I_{0}-I_{c}}{I_{0}}\right)
\end{gathered}
$$

The reverse saturation current of diode $\left(I_{0}\right)$ is constant under the constant temperature and found by setting the open-circuit condition, the open circuit voltage is obtained as:

$$
V_{o c}=\frac{k T_{c}}{q} \ln \left(\frac{I_{P h}+I_{0}}{I_{0}}\right)
$$

As $I_{p h} \gg I_{0}$ above equation can be written as:

$$
V_{o c}=\frac{k T_{c}}{q} \ln \left(\frac{I_{P h}}{I_{0}}\right)
$$

To a very good approximation, the photon generated current, which is equal to $I_{s c}$, is directly proportional to the irradiance, the intensity of illumination, to PV cell. Thus, if the value, $I_{s c}$, is known from the datasheet, under the standard test condition, $S_{c}=1000 \mathrm{~W} / \mathrm{m}^{2}$ at the air mass $(\mathrm{AM})=1.5$, then the photon generated current at any other irradiance, $S_{x}$ in $\left(\mathrm{W} / \mathrm{m}^{2}\right)$, is given by:

$$
I_{s c-s x}=\left(\frac{S_{x}}{S_{c}}\right) I_{s c-s c}
$$

\subsection{More Accurate Model (Non-Ideal Case)}

Some researchers on photovoltaic models use constant parameters (i.e. ideality factor A, series resistance $R_{s}$, and shunt resistance $R_{p}$,), which result in modeling inaccuracy. In reality, these parameters vary with the temperature change. For better results consideration of these effects is necessary. Figure 8 shows a more accurate equivalent circuit of a PV cell [4].

\subsubsection{Series Resistance}

In a practical PV cell, there is a series of resistance in a current path through the semiconductor material, the metal grid, contacts, and current collecting bus. These resistive losses are lumped together as a series resister $\left(R_{s}\right)$. Its effect becomes very conspicuous in a PV module that consists of many series-connected cells, and the value of resistance is multiplied by the number of cells.

\subsubsection{Parallel Resistance}

This is also called shunt resistance. It is a loss associated with a small leakage of current through a resistive path in parallel with the intrinsic device. This can be represented by a parallel resister $\left(R_{p}\right)$. Its effect is much less conspicuous in a PV module compared to the series resistance, and it will only become noticeable when a number 


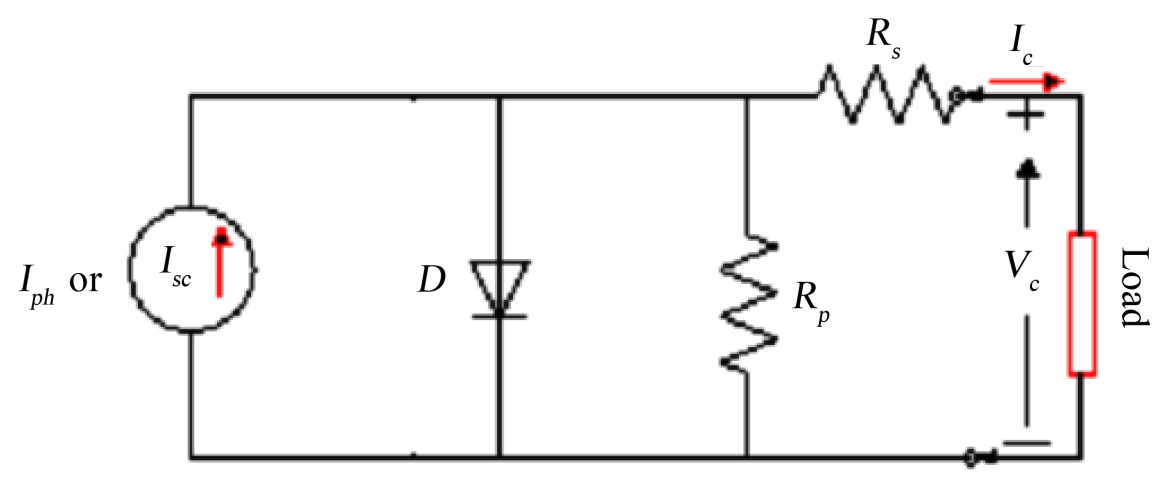

Figure 8. Equivalent circuit of PV cell (non ideal case).

of PV modules are connected in parallel for a larger system [5].

$$
I_{c}=I_{P h}-I_{0}\left[\mathrm{e}^{q\left(\frac{V_{c}+I_{c} R_{s}}{A k k_{c}}\right)}-1\right]-\left(\frac{V_{c}+I_{c} R_{s}}{R_{p}}\right)
$$

where $A$ is known as the "ideality factor of junction" (" $A$ " is sometimes denoted as " $n$ "). After rearranging the above equation we can write $\mathrm{I}-\mathrm{V}$ equation as shown below:

$$
V_{c}=\frac{A k T_{c}}{q} \ln \left(\frac{I_{P h}+I_{0}-I_{c}}{I_{0}}\right)-\left(\frac{V_{c}+I_{c} R_{s}}{I_{0} R_{P}}\right)-I_{c} R_{s}
$$

\section{Modeling of Solar PV System Using Matlab Simulink}

The MATLAB/SIMULINK software has been used for the modeling and simulation purposes [3] [6].

Model and circuit design for PV array are shown in Figure 9 and Figure 10 respectively.

C. Parameters used in PV module for the different characteristics;

A. I-V characteristics of solar array at variable solar insolation, $25^{\circ} \mathrm{C}$;

B. P-V characteristics at variable solar insolation, $25^{\circ} \mathrm{C}$;

C. I-V characteristics at variable temperature, $1000 \mathrm{~W} / \mathrm{m}^{2}$;

D. P-V characteristics at variable temperature, $1000 \mathrm{~W} / \mathrm{m}^{2}$;

E. I-V curve for different values of Nss and Npp at standard conditions;

F. P-V curve for different values of Nss and Npp at standard conditions.

\section{Conclusions}

In order to answer the present energy crisis, one has to develop an efficient manner in which power has to be extracted from the incoming solar radiation. The power conversion mechanisms have been greatly reduced in size in the past few years. The development in power electronics and material science has helped engineers to come up very small but powerful systems to withstand the high power demand. But the disadvantage of these systems is the increased power density.

The constant increase in the development of the solar cells manufacturing technology will definitely make the use of these technologies possible on a wider basis. The use of the newest power control mechanisms called the Maximum Power Point Tracking (MPPT) algorithms has led to the increase in the efficiency of operation of the solar modules and thus is effective in the field of utilization of renewable sources of energy [7].

Here, in this paper, the performance characteristics of SPV arrays have been analyzed by varying temperature and solar irradiation. The open circuit voltage decreases linearly with the increase in the cell temperature and open circuit voltage increases logarithmically with the ambient irradiation, while the short circuit current is a linear function of the ambient irradiation. The value of parameters used in SPV module is shown in Table 1. I-V characteristics \& P-V characteristics of Solar Array with variation of solar insolation \& temperature are shown in Figures 11-14. I-V \& P-V characteristics with different number of cells are shown in Figure 15 \& Figure 16. 


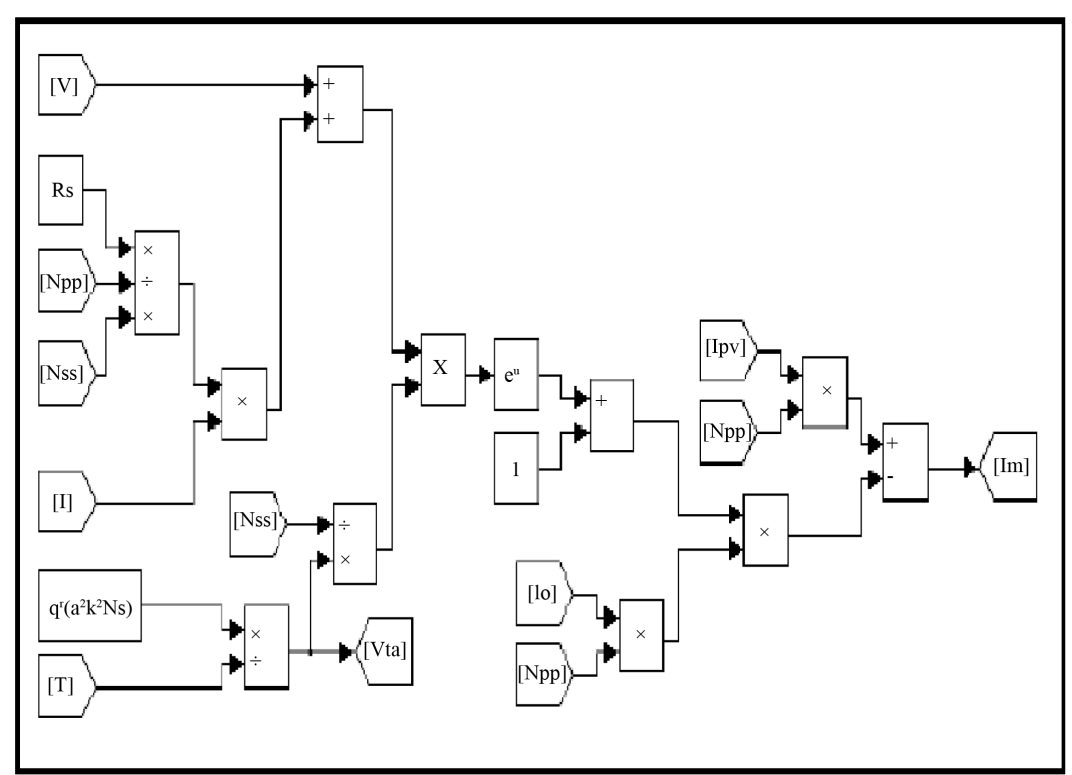

Figure 9. Simulated model of SPV array.

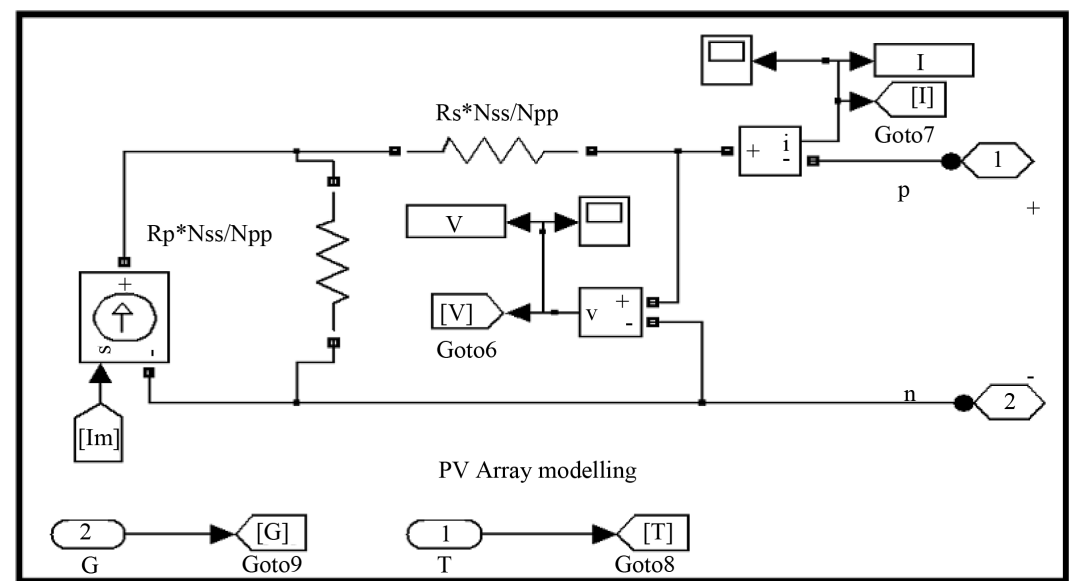

Figure 10. Circuit design of SPV array.

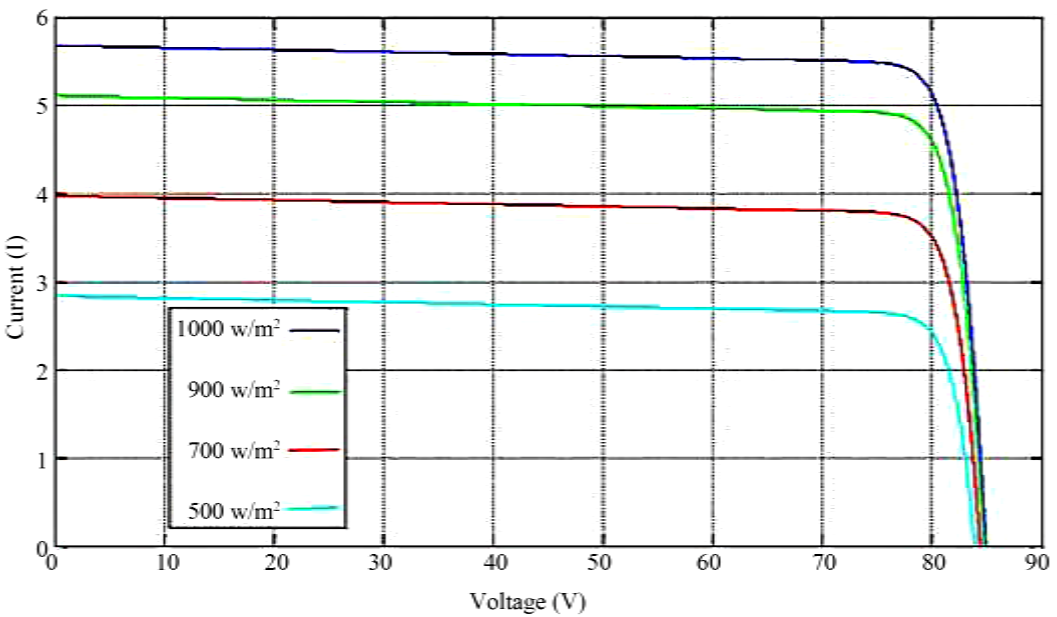

Figure 11. I-V characteristics at variable solar insolation at $25^{\circ} \mathrm{C}$. 


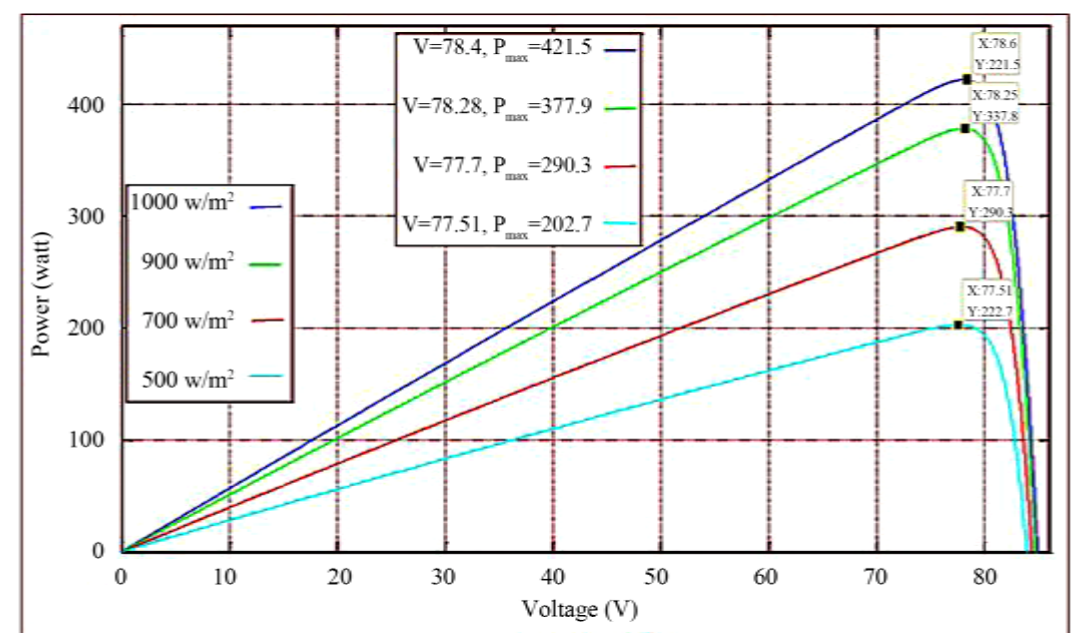

Figure 12. P-V characteristics at variable solar insolation at $25^{\circ} \mathrm{C}$.

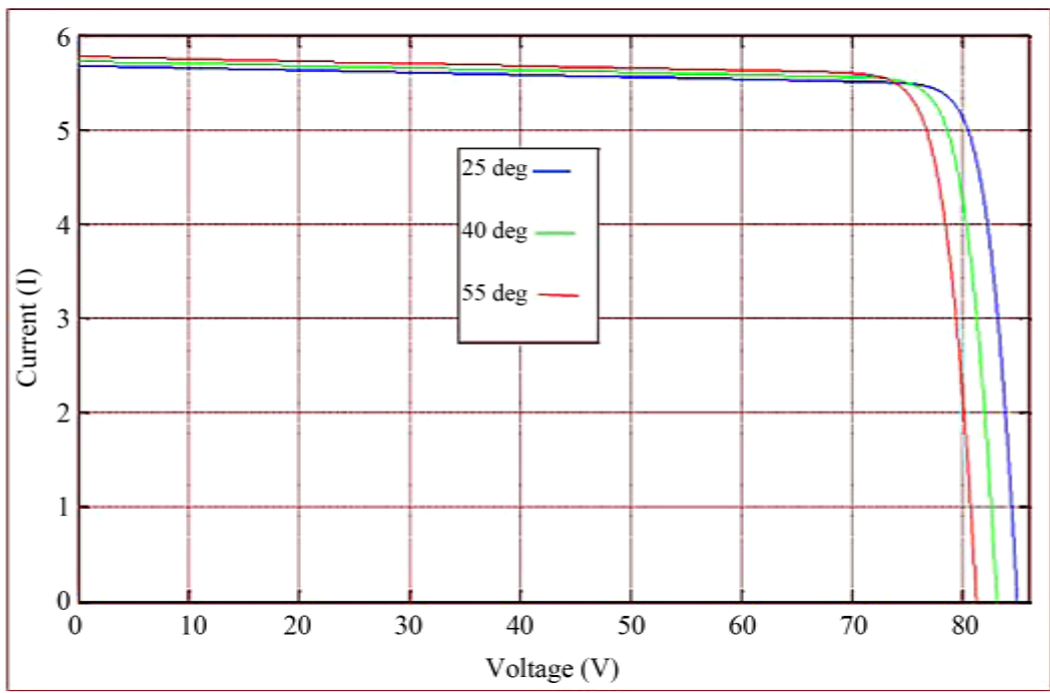

Figure 13. I-V characteristics at variable temperature, constant insolation.

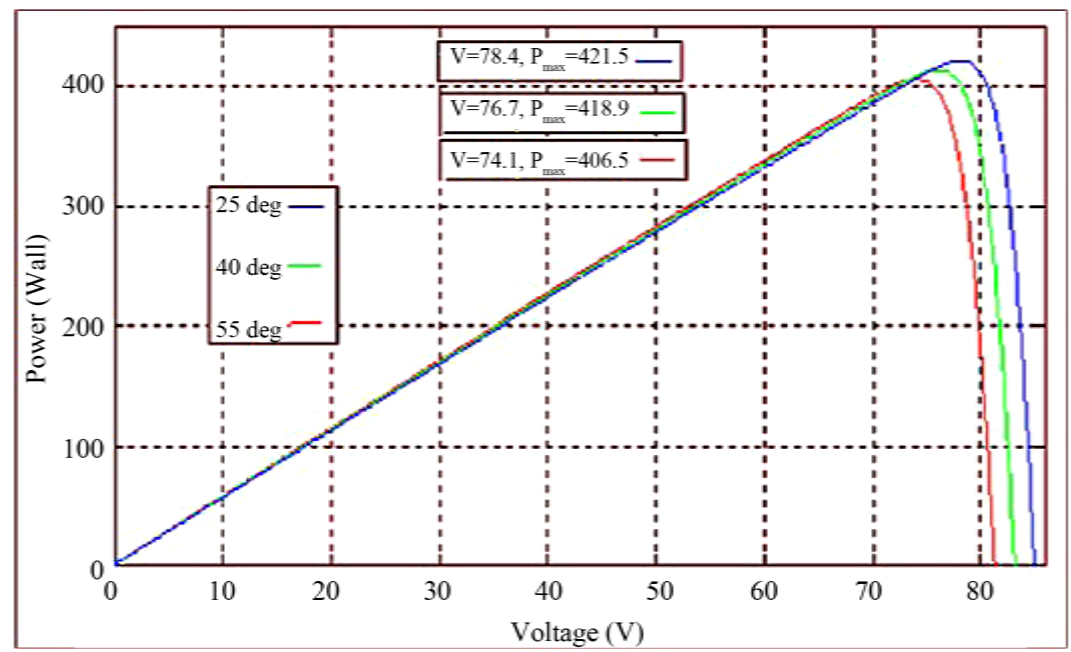

Figure 14. P-V characteristics at variable temperature, constant insolation. 


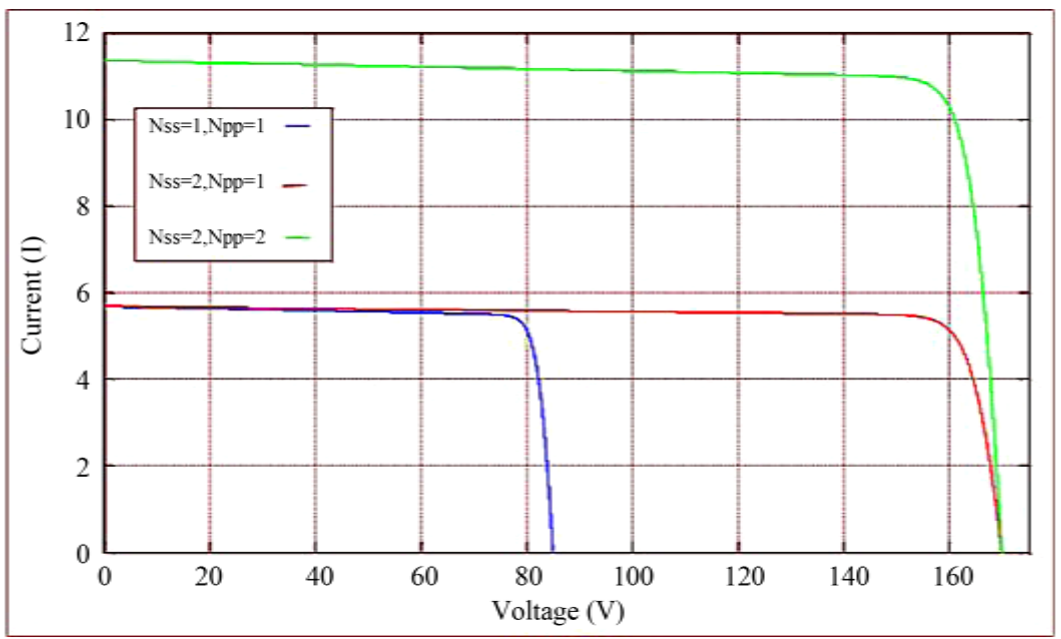

Figure 15. I-V curve for different values of Nss and Npp.

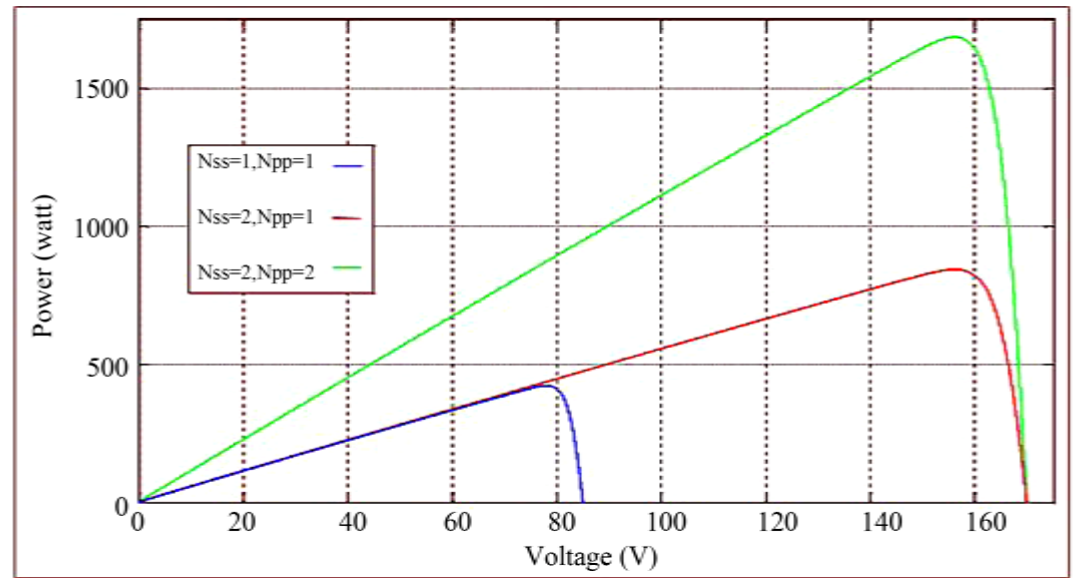

Figure 16. P-V curve for different values of Nss and Npp.

Table 1. Parameters value of PV module.

\begin{tabular}{ccc}
\hline S. No. & Parameters & Value \\
1 & Voc & $85 \mathrm{~V}$ \\
2 & $\mathrm{Isc}$ & $5.68 \mathrm{~A}$ \\
3 & $\mathrm{Ki}$ & $0.0032 \mathrm{~A} / \mathrm{K}$ \\
4 & $\mathrm{Kv}$ & $-0.1230 \mathrm{~V} / \mathrm{K}$ \\
5 & $\mathrm{Ns}$ & 54 \\
6 & $\mathrm{Nss}$ & 1 \\
7 & $\mathrm{Npp}$ & 1 \\
8 & $\mathrm{Imp}$ & $5.4 \mathrm{~A}$ \\
9 & $\mathrm{Vmp}$ & $78.4 \mathrm{~V}$ \\
10 & $\mathrm{Rs}$ & $0.221 \mathrm{ohm}$ \\
\hline
\end{tabular}

By analyzing these results, one can see the effects of partial shading on SPV arrays as future work. 


\section{References}

[1] Ramos Hernanz, J.A., Campayo Martin, J.J. and Zamora Belver, I. (2010) Modelling of Photovoltaic Module. International Conference on Renewable Energies \& Power Quality. Granada, 23-25 March 2010.

[2] Villalva, M.G., Gazoli, J.R. and Filho, E.R. (2009) Comprehensive Approach to Modelling \& Simulation of PV Arrays. IEEE Transactions on Power Electronics, 25, 1198-1208.

[3] Salmi, T., Bouzguenda, M., Gastli, A. and Masmoudi, A. (2012) Matlab/Simulink Based Modelling of Solar Photovoltaic Cell. International Journal of Renewable Energy Research, 2.

[4] Ghosh, S.K. (2013) Modelling of PV Arrays \& Analysis of Different Parameters. International Journal of Advancements in Research \& Technology, 2, 358-3623.

[5] Pongratananukul, N. Analysis \& Simulation Tools for SPV Power Systems. PhD Dissertation, University of Central Florida, Orlando.

[6] Pandiarajan, N. and Muthu, R. (2011) Mathematical Modelling of Photovoltaic Module with Simulink. International Conference on Electrical Energy Systems (ICEES 2011), Newport Beach, 3-5 January 2011, 258-263. http://dx.doi.org/10.1109/ICEES.2011.5725339

[7] Khan, B.H. (2009) Non-Conventional Energy Resources. TMH. 